\title{
Composite Film of Chitosan Loaded Norfloxacin With Improved Flexibility and Antibacterial Activity for Wound Dressing Application
}

\author{
NOR JANNAH MOHD SEBRI ${ }^{1}$ and KHAIRUL ANUAR MAT AMIN ${ }^{1,2}$ \\ 1School of Fundamental Science, Universiti Malaysia \\ Terengganu, 21030, Kuala Terengganu, Malaysia. \\ 2Institute of Marine Biotechnology, University Malaysia \\ Terengganu, 21030 Terengganu, Malaysia. \\ *Corresponding author E-mail: kerol@umt.edu.my \\ http://dx.doi.org/10.13005/ojc/330210
}

(Received: December 19, 2016; Accepted: February 22, 2017)

\begin{abstract}
This research develops chitosan film incorporated norfloxacin ( $\mathrm{CH}-\mathrm{NOR}$ ) designed to combat the infection of bacteria around the wound area. Inclusion of norfloxacin increased the strain-atbreak or flexibility of the film. Swelling behavior and water vapor transmission rates (WVTRs) values are improved and optimum for CH-NOR1.0 film at $524 \pm 65 \%$ and $1916 \pm 78 \mathrm{~g} \mathrm{~m}^{-2} \mathrm{~d}^{-1}$, respectively. In-vitro cell studies show that the present of norfloxacin in $\mathrm{CH}$ film gradually decreased the number of human dermal fibroblast cell (CRL2522, ATCC) after incubated for 72 hours. In-contrast, antibacterial activities of $\mathrm{CH}-\mathrm{NOR}$ films exhibit strong inhibition zones against Gram-positive (Staphylococcus aureus and Bacillus cereus) and Gram-negative (Escherichia coli and Klebsiella pneumoniae) bacteria.
\end{abstract}

Keywords: Chitosan, Norfloxacin, Film, Biomaterials, Wound dressing.

\section{INTRODUCTION}

Chitosan $(\mathrm{CH})$ is an attractive polymer to be considered for medical applications as they are biocompatible and biodegradable. It is a linear cationic polysaccharide, and one of the most abundant polysaccharides occurring in nature. It is structurally similar to the extracellular matrix component glycosaminoglycans (GAGs) and has been utilized in the field of biomedicine as dressing materials ${ }^{1}$, scaffolds ${ }^{2}$ and pharmaceuticals delivery agent $^{3}$ by promoting bone cell division as well as bone growth. It is also used in other applications such as contact lenses ${ }^{4}$, anticoagulant ${ }^{5}$ and anticancer substances $^{6}$. The ease of $\mathrm{CH}$ fabrication to form variety of products such as gels, scaffolds, films, 
filaments, powders, sponges, composite or as nanofibers further accelerates the usability of this material ${ }^{7}$.

Various studies have been reported on developing $\mathrm{CH}$ film as dressing products by incorporating difference therapeutic agents or specifically antibiotic agents. Sezer and coworkers introduced fucoidan into porous $\mathrm{CH}$ film to investigate its suitability for the treatment of dermal burns on rabbits ${ }^{8}$. The results show that fucoidan$\mathrm{CH}$ film has the fastest closure of wounds after 14 days compared with other treatments. Many other therapeutic agents have been reported in $\mathrm{CH}$ films such as amikacin and dapromycin ${ }^{9}$, ciprofloxacin hydrochloride ${ }^{10}$ and ornidazole ${ }^{11}$. Antibiotics derived from fluoroquinolone groups are among the rapid growing class of antimicrobial agents that has proved the effectiveness in treatment of bacterial infection $^{12}$. All the fluoroquinolone groups have a fluorine at position 6 of a naphthyridine ring and few of them are levofloxacin, gatifloxacin, lemofloxacin and norfloxacin with different functional groups $\left(R_{1}, R_{2}, R_{3} \text { and } R_{4}\right)^{13}$. Norfloxacin has a broad spectrum of activity against Gram-positive and Gram-negative bacteria especially aerobes with limited activity against anaerobes ${ }^{14}$. It is also effective in treatments of a wide range of clinical infections including the urinary tract, ${ }^{15}$ and liver cirrhosis ${ }^{16}$. Having said this norfloxacin can combat lot of bacteria, limited studies have been discussed on the effect of norfloxacin in biopolymer composite film to be applied as wound dressing materials. Chitosan sponges with norfloxacin have been examined and show excellent antibacterial activity proportional to the release rate ${ }^{17}$. Other study reported on chitosan microsphere loaded norfloxacin with improved antibacterial effect ${ }^{18}$. Different biopolymer, i.e. polyvinyl alcohol (PVA) film containing norfloxacin $(5 \% \mathrm{w} / \mathrm{w})$ also show comparable in-vitro performances and healing effects to commercial silver sulfadiazine $(1 \% \mathrm{w} / \mathrm{w}) \mathrm{cream}^{19}$.

In this study, we highlighted the properties of $\mathrm{CH}$ film loaded with norfloxacin ( $\mathrm{CH}-\mathrm{NOR}$ ) as an effective material to combat the bacteria. Not limited to that, the mechanical performances, physical properties such as swelling capability and water vapor transmission rates of the $\mathrm{CH}-\mathrm{NOR}$ film are examined to optimize the properties of the materials. The cell viability and cell proliferation tests are also carried out to study the biocompatibility of the CH-NOR films involved human skin fibroblast cell (CRL2522, American Type Tissue Collection), while the antibacterial activities of the samples were assessed via in-vitro qualitative study against Gram-positive and Gram-negative bacteria.

\section{MATERIALS AND METHODS}

\section{Materials}

Chitosan $(\mathrm{CH}$ : medium molecular weight, $75 \%$ degree of deacetylation (DD), viscosity $\approx 453 \mathrm{cP}$ ) and glacial acetic acid were obtained from Sigma Aldrich, St Louis, MO while penicillin G-P10 was obtained from Oxoid, England. Norfloxacin was obtained from Fluka, Malaysia. All materials were used as received without further purification.

\section{Preparation of chitosan with norfloxacin}

Chitosan $(\mathrm{CH})$ solution was prepared by dissolving $2 \% \mathrm{w} / \mathrm{w}$ in acetic acid $(0.1 \mathrm{M})$ and heated for $2 \mathrm{~h}$ at $70{ }^{\circ} \mathrm{C}$. Glycerin $(30 \%$, w/w) was added into the $\mathrm{CH}$ solution followed by norfloxacin $(0.1,1.0$ and $5.0 \% \mathrm{w} / \mathrm{w}$ ) henceforth referred to as $\mathrm{CH}-\mathrm{NOR} 0.1$, $\mathrm{CH}-\mathrm{NOR} 1.0$ and $\mathrm{CH}-\mathrm{NOR} 5.0$, respectively. The $\mathrm{CH}$ solutions were then cooled in ambient temperature for $24 \mathrm{~h}$ to let the debris and extraneous matter precipitated at the bottom of the beaker, forming a clear yellowish solution. The $\mathrm{CH}$ solutions were then poured onto an acrylic plate and dried in oven at $50{ }^{\circ} \mathrm{C}$ for 24 hours.

\section{Characterization ATR-FTIR}

ATR-FTIR spectra were collected using a Perkin Elmer Spectrum 100 FTIR spectrophotometer with PIKE Miracle ATR accessory (single-bounce beam path, $45^{\circ}$ incident angle, 16 scans, and $4 \mathrm{~cm}^{-1}$ resolution). All spectra were corrected by the Perkin Elmer Spectrum 100 software.

\section{Mechanical properties}

Tensile strength measurements were obtained using an Instron Universal Testing machine (model 3366) with $\pm 10 \mathrm{kN}$ grips and cross-speed set at $10 \mathrm{~mm} / \mathrm{min}$ according to ASTM standard method D 882-01. All films were cut to $20 \mathrm{~mm}$ x $60 \mathrm{~mm}$, and film's thickness was measured using a Mitutoyo hand-held micrometre. Young's modulus (E), tensile 
strength (TS), and toughness (T) were calculated from the slope of the linear part of the stress-strain curve, the maximum stress, and by integrating the area under the stress-strain curve, respectively. A minimum of three independent measurements were obtained per sample.

\section{Swelling Analysis}

The swelling test was carried out by immersing dried films $(20 \mathrm{~mm} \times 20 \mathrm{~mm})$ in phosphate buffer solution $(\mathrm{pH} 7)$ in water bath $\left(37 \pm 0.5^{\circ} \mathrm{C}\right)$. The samples were then removed after $24 \mathrm{~h}$, lightly blotted with a wet filter paper to expel surface solution prior to measuring the weight. The test was repeated triplicates for each ratio. Finally, the swelling degree was then determined from the equilibrium-swelling ratio:

$$
\begin{aligned}
& \text { Swelling Degree, SD (\%)=( } \left.M_{w}-M_{d}\right) / M_{d} \\
& \text { where } M_{w}=\text { Weight of swollen sample and } M_{d} \\
& \text { = Weight of dry sample }
\end{aligned}
$$

\section{Water Vapor Transmission Rate}

The water vapor transmission rate (WVTR) test was carried out using the method adapted from the previous study ${ }^{20}$. Briefly, films with dimension of $30 \mathrm{~mm} \times 30 \mathrm{~mm}$ was cut and put as a cap of a glass vial with a diameter $16 \mathrm{~mm}$ containing $10 \mathrm{~mL}$ distilled water, followed by the system being weighed and recorded. Each ratio of samples was made into triplicates and stored in humidity chamber for $24 \mathrm{~h}$ at $\mathrm{T}=37.5^{\circ} \mathrm{C}$ and relative humidity of $60 \% \pm$ 5. The value for WVTR $\left(\mathrm{g} \mathrm{m}^{-2} \mathrm{~d}^{-1}\right)$ was calculated as follows;

$$
\text { WVTR }=\left(W_{i}-W_{f}\right) /(A)
$$

where $A=$ area of the vial opening, $W_{i}=$ initial weight of the system and $W_{f}=$ final weight of the system.

\section{Cell Study}

\section{Routine cell-culture}

The cultivation of normal human skin fibroblast cells (CRL-2522, ATCC) was prepared by using the Eagle's Minimum Essential Medium (EMEM, ATCC, USA) with $10 \%(\mathrm{v} / \mathrm{v})$ fetal bovine serum (FBS, Sigma Aldrich, USA) and 1\% (v/v) antibiotic (Penicillin/ Streptomycin, Sciencell, USA).
In addition, the cells were cultured at $37{ }^{\circ} \mathrm{C}$ in a humidified $5 \% \mathrm{CO}_{2}$ atmosphere and were subcultured every three days as established protocols and harvested at $60-80 \%$ confluence.

\section{Cell Viability}

The chitosan films (diameter $\sim 6 \mathrm{~mm}$ ) were placed into the 96-well culture plates (Nunc, Germany) containing EMEM medium prior to sterilize in a laminar airflow chamber under UV radiation for 20 minutes. The $\mathrm{CH}$ films were sterilized in a laminar airflow chamber under UV radiation for $20 \mathrm{~min}$. The next step followed with having three replicates used for each type of samples. The CRL2522 cells (5000 cells/ well) were seeded into wells containing samples and cultured at $37^{\circ} \mathrm{C}$ in $5 \% \mathrm{CO}_{2}$ atmosphere. Tissue culture polystyrene plates (TCPP) were used as a control, and after $24 \mathrm{~h}, 48 \mathrm{~h}$, and $72 \mathrm{~h}$ of incubation, the cell viability were observed by using an Olympus TH4-200 microscope equipped with an Olympus U-RFL-T UV pack stained with calcein-AM.

\section{Cell Proliferation}

Cell proliferations were quantified by using CellTiter 96 aqueous one solution assay (Promega, USA), which contained tetrazolium compound [3-(4, 5-dimethylthiazol-2-yl)-5(3- carboxymethoxyphenyl)-2-(4-sulfophenyl)$2 \mathrm{H}$ tetrazolium), inner salts; MTS (a)] with electroncoupling reagent (phenazineethosulfate). Prior to the addition of the assay solution $(20 \mu \mathrm{L}$ in each wells), the media in all wells that contained samples, except for the positive control, were replaced with fresh media and later incubated for $3 \mathrm{~h}$ at $37^{\circ} \mathrm{C}$ in an atmosphere containing $5 \% \mathrm{CO}_{2}$. Then, $100 \mu \mathrm{L}$ of the inoculants were transferred into new wells and the absorbance at $490 \mathrm{~nm}$ was measured by using a microplate reader (Multiskan Ascent 96/384, USA). The absorbance readings were converted to cell number using calibration curves.

\section{Antibacterial Study}

Gram-positive (Staphylococcus aureus \& Bacillus cereus) and Gram-negative (Escherichia coli \& K. pneumoniae) bacterial suspensions were used for the antibacterial assay. Mueller-Hinton $(\mathrm{MH}$, Difco, Malaysia) agar was used for the growth of both bacterial types. Each Gram-positive and Gram-negative bacteria suspension was evenly 
spread on the solid $\mathrm{MH}$ agar and dried in a laminar flow air chamber. The samples (diameter $\sim 6 \mathrm{~mm}$ ) were adhered on the agar surface. The LB agar with the $\mathrm{CH}$ film samples was incubated at $37^{\circ} \mathrm{C}$ for 24 hours. The presence of any clear zone around the film on the LB agar was recorded as an indication of inhibition against the $S$. aureus, B. cereus, E. coliand K. pneumoniae.

\section{RESULTS AND DISCUSSIONS}

\section{ATR-FTIR}

Fig. 1 shows the ATR-FTIR spectra of chitosan $(\mathrm{CH})$ films incorporated with norfloxacin. Three major shifting steps are observed in the $\mathrm{CH}$

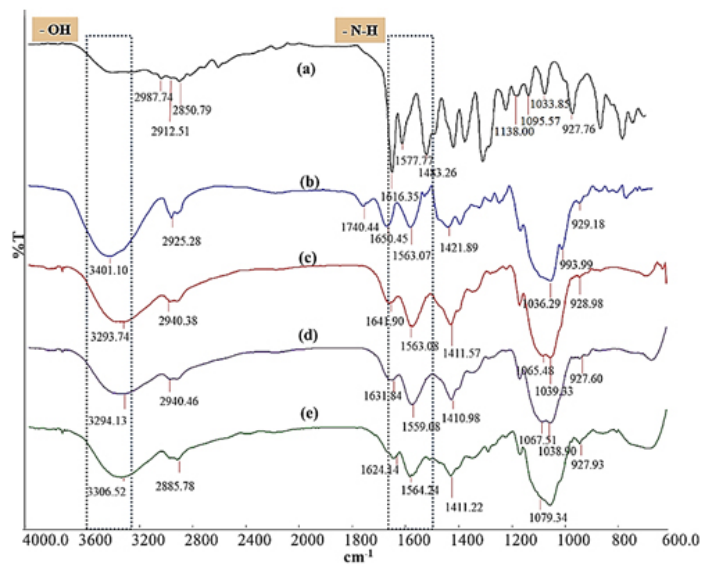

Fig. 1: ATR-FTIR spectra of; (a) norfloxacin, (b) $\mathrm{CH}$ film, (c) CH-NOR0.1 film (d) CH-NOR1.0 film, and (e) CH-NOR5.0 film.

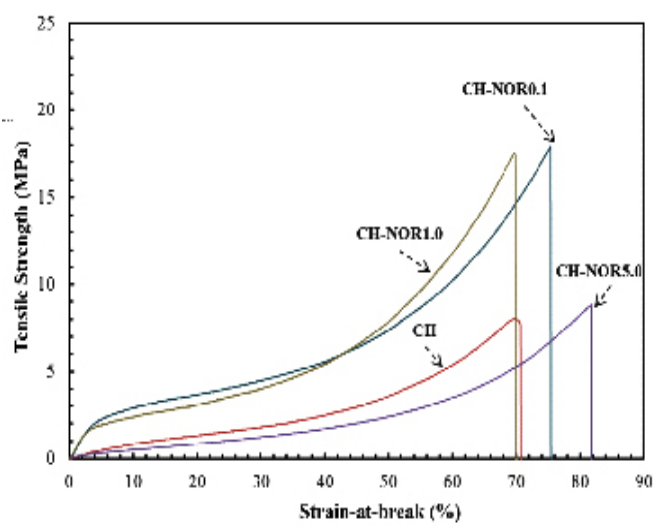

Fig. 2: Tensile strength vs strain-at-break curve of chitosan film $(\mathrm{CH})$ and $\mathrm{CH}$ films added with norfloxacin: CH-NORO.1, CH-NOR1.0 and CH-NOR5.0 film spectrum upon addition of norfloxacin, i.e. shifting of the broad band of $-\mathrm{OH}$ stretching $\left(3401.10 \mathrm{~cm}^{-1}\right)$, antisymmetric deformation of $\mathrm{N}-\mathrm{H}$ vibration in $\mathrm{NH}_{3}{ }^{+}$ ions $\left(1650.45 \mathrm{~cm}^{-1}\right)$ and $\mathrm{C}-\mathrm{H}$ bending functional group $\left(1421 \mathrm{~cm}^{-1}\right)$. The broad band of $-\mathrm{OH}$ stretching in $\mathrm{CH}$ films at $3401.10 \mathrm{~cm}^{-1}$ shifted upon addition of norfloxacin, i.e. CH-NOR0.1, CH-NOR1.0 and $\mathrm{CH}-\mathrm{NOR} 5.0$ at $3293.74 \mathrm{~cm}^{-1}, 3294.13 \mathrm{~cm}^{-1}$ and $3306.52 \mathrm{~cm}^{-1}$, respectively. According to Pierog and co-workers, the shifting occurred within this range indicates the formation of hydrogen bonding from the interaction of $\mathrm{O}-\mathrm{H}$ (norfloxacin) and $\mathrm{N}-\mathrm{H}$ (chitosan) stretching vibrations ${ }^{21}$. The shifting of $1650.45 \mathrm{~cm}^{-1}$ peak of $\mathrm{CH}$ film was also observed in $\mathrm{CH}-\mathrm{NOR}$ films ranging from $1624-1641 \mathrm{~cm}^{-1}$ which was assigned to antisymmetric deformation of $\mathrm{N}-\mathrm{H}$ vibration in $\mathrm{NH}_{3}{ }^{+}$ ions. Meanwhile, the $\mathrm{C}-\mathrm{H}$ bending functional group of $\mathrm{CH}$ film at $1421.89 \mathrm{~cm}^{-1}$ shifted to almost similar wavelength at $1411 \mathrm{~cm}^{-1}$ for $\mathrm{CH}-\mathrm{NOR} 01, \mathrm{CH}-\mathrm{NOR} 1.0$ and $\mathrm{CH}-\mathrm{NOR} 5.0$ films. Other than that, the inclusion of norfloxacin also caused the carbonyl group $(\mathrm{C}=\mathrm{O})$ at $1740.44 \mathrm{~cm}^{-1}$ in $\mathrm{CH}$ film disappear in all $\mathrm{CH}-\mathrm{NOR}$ films. This could indicate that carbonyl group $(\mathrm{C}=\mathrm{O})$ of chitosan, i.e. amide group, is possibly involved in the interaction between chitosan and norfloxacin through hydrogen bonding.

\section{Mechanical properties}

The mechanical properties of the $\mathrm{CH}$ film with inclusion of norfloxacin are shown in Fig. 2 and summarized in Table 1. The addition of norfloxacin into $\mathrm{CH}$ resulted in increased strain-at-break $(\gamma)$ at a cost of decreased tensile strength (TS) of the film, whereby $\mathrm{CH}-\mathrm{NOR} 5.0$ film exhibited the $\gamma$ at $80 \pm 1$ $\%$ and $9 \pm 1 \mathrm{MPa}$ for TS (Table 1). For comparison, the $\gamma$ of $\mathrm{CH}$-NOR0.1 film (lowest concentration of norfloxacin) was recorded at $71 \pm 4 \%$ and 15 $\pm 3 \mathrm{MPa}$ for TS. Nevertheless, all the $\mathrm{CH}$ films with norfloxacin show higher mechanical properties (TS, YM, T and $\gamma$ ) than $\mathrm{CH}$ free-standing film (Table 1).

The improvement in the mechanical properties of the $\mathrm{CH}$-NOR films could result from hydrogen bonding between $\mathrm{CH}$ with norfloxacin as discussed in ATR-FTIR results. Previous studies have also reported that the increased strain-at-break in polymer-synthetic polymers composites can be attributed to the formation of hydrogen bonding between the chitosan and poly( $\epsilon$-caprolactone $)^{22}$. Besides that, we could also suggest that the 
mechanical reinforcement in composite materials is due to the good film forming property between the polymers used ${ }^{23}$.

\section{Swelling and water vapor transmission rates}

The swelling results show that the addition of norfloxacin to the $\mathrm{CH}$ film resulted in increasing of the water uptake (Table 1). $\mathrm{CH}$ films absorbed $292 \pm 24 \%$ in phosphate buffer solution $(\mathrm{pH} 7.2)$ and increased to $524 \pm 65 \%$ for $\mathrm{CH}-\mathrm{NOR} 1.0$ films. For $\mathrm{CH}$ free-standing film, it has been suggested that the swelling of $\mathrm{CH}$ materials is a result of electrostatic repulsion between $\mathrm{CH}$ chains ${ }^{24}$. With the addition of norfloxacin, the electrostatic repulsion between $\mathrm{CH}$ chains has been perturbed and new bonding between $\mathrm{CH}$ and norfloxacin caused the swelling value has increased. Similar results have been observed for water swelling of chitosan sponge with norfloxacin in which the swelling ratio was increased by increasing the norfloxacin content ${ }^{17}$. Nevertheless, the swelling degree has decreased for $\mathrm{CH}-\mathrm{NOR} 5.0$ films probably due to the higher compactness in $\mathrm{CH}$ film (increased crosslinking by norfloxacin) thus hindering the water absorption and permeability of the film ${ }^{25}$. In higher crosslinked/ polymer ratio, the crosslinking density increased and eventually reduced the swelling or water uptake of the films significantly.

Swelling percentage and WVTR values obtained in this particular study are correlated due to the fact that both properties exhibit affinity of the film towards water molecule. Water vapor transmission rates (WVTR) values of the $\mathrm{CH}$-NOR films are shown in Table 1. The WVTR value of the $\mathrm{CH}$ film was recorded at $1682 \pm 170 \mathrm{~g} \mathrm{~m}^{-2} \mathrm{~d}^{-1}$ and inclusion of norfloxacin increased the WVTR values to 1883 $\pm 43 \mathrm{~g} \mathrm{~m}^{-2} \mathrm{~d}^{-1}$ for $\mathrm{CH}-\mathrm{NOR} 0.1$ film, followed by $\mathrm{CH}$ -
NOR1.0 at $1916 \pm 78 \mathrm{~g} \mathrm{~m}^{-2} \mathrm{~d}^{-1}$. For CH-NOR5.0 film, the WVTR value was decreased to $1795 \pm 64 \mathrm{~g} \mathrm{~m}^{-2}$ $\mathrm{d}^{-1}$ due to higher compactness in $\mathrm{CH}$ film ${ }^{26}$. These values $\left(1682-1916 \mathrm{~g} \mathrm{~m}^{-2} \mathrm{~d}^{-1}\right)$ are within the range of 8 commercially available wound dressing materials from 90 to $2893 \mathrm{~g} \mathrm{~m}^{-2} \mathrm{~d}^{-127}$. For instance, the optimum WVTR value is important since both moisture and oxygen are very quintessential during wound healing. For chitosan films, the WVTR values are affected by several factors such as deacetylation degree and molecular weight of chitosan, film thickness, temperature and relative humidity of measuring condition ${ }^{28}$.

\section{Cell Cytotoxicity}

The cell's viability of $\mathrm{CH}-\mathrm{NOR}$ films stained with Calcein-AM on human dermal fibroblast cell (CRL2522, ATCC) and incubated for $24 \mathrm{~h}, 48 \mathrm{~h}$ and $72 \mathrm{~h}$ is shown in Fig. 3. The CRL2522 cells adhering on $\mathrm{CH}$ film changed their morphology from spherical to elongated, which is typical for fibroblast cells (Fig. 3[d-f]). Previous study has suggested that the adherence of fibroblast cells on $\mathrm{CH}$ film is a result of an electrostatic interaction between positively charged $\mathrm{CH}$ chains and negatively charged fibroblast cell membrane 29 . The attachment and growth of CRL2522 cell on $\mathrm{CH}$ films are in agreement with previous studies examined against other fibroblast cells ${ }^{30}$.

The addition of norfloxacin to $\mathrm{CH}$ films generally promotes the cell growth after being incubated for $24 \mathrm{~h}$. For instance, fluorescence imaging shows that the cells on $\mathrm{CH}-\mathrm{NOR}$ films is viable (Fig. $3[\mathrm{~g}, \mathrm{j}, \mathrm{m}]$ ). However, the degree of fluorescence observed for cells incubated for 72 hours especially on $\mathrm{CH}-\mathrm{NOR} 5.0$ films gradually decreased which could possibly indicate that the cells

Table 1: Summary of the tensile strength (TS), Young's modulus (YM), toughness $(\mathrm{T})$, strain-at-break $(\gamma)$, swelling and water vapor transmission rates (WVTRs) of chitosan films with norfloxacin.

\begin{tabular}{lcccccc}
\hline Sample & $\begin{array}{c}\text { TS } \\
(\mathbf{M P a})\end{array}$ & $\begin{array}{c}\mathbf{Y M} \\
\mathbf{( M P a})\end{array}$ & $\begin{array}{c}\mathbf{T} \\
\left(\mathbf{J ~ g ~}^{-1}\right)\end{array}$ & $\begin{array}{c}\gamma \\
(\%)\end{array}$ & $\begin{array}{c}\text { Swelling } \\
\mathbf{( \% )}\end{array}$ & $\begin{array}{c}\text { WVTR } \\
\left(\mathbf{g ~ m}^{-2} \mathbf{~ d}^{-1}\right)\end{array}$ \\
\hline CH & $7 \pm 1$ & $28 \pm 3$ & $1.0 \pm 0.01$ & $71 \pm 6$ & $292 \pm 24$ & $1682 \pm 170$ \\
CH-NOR0.1 & $18 \pm 3$ & $48 \pm 12$ & $2.2 \pm 0.01$ & $75 \pm 4$ & $320 \pm 21$ & $1883 \pm 43$ \\
CH-NOR1.0 & $17 \pm 6$ & $65 \pm 11$ & $2.5 \pm 0.9$ & $70 \pm 5$ & $524 \pm 65$ & $1916 \pm 78$ \\
CH-NOR5.0 & $8 \pm 1$ & $29 \pm 2$ & $1.1 \pm 0.14$ & $82 \pm 1$ & $287 \pm 16$ & $1795 \pm 64$ \\
\hline
\end{tabular}


are dying (Fig. $3[i, I, o])$. To quantify the cell growth on $\mathrm{CH}-\mathrm{NOR}$ films, cell proliferation was carried out by using CellTiter 96 aqueous one solution assay. The cell proliferation results clearly show that the inclusion of norfloxacin significantly affected the cell growth (Fig. 3 [p]). For example, CH-NOR0.1 film

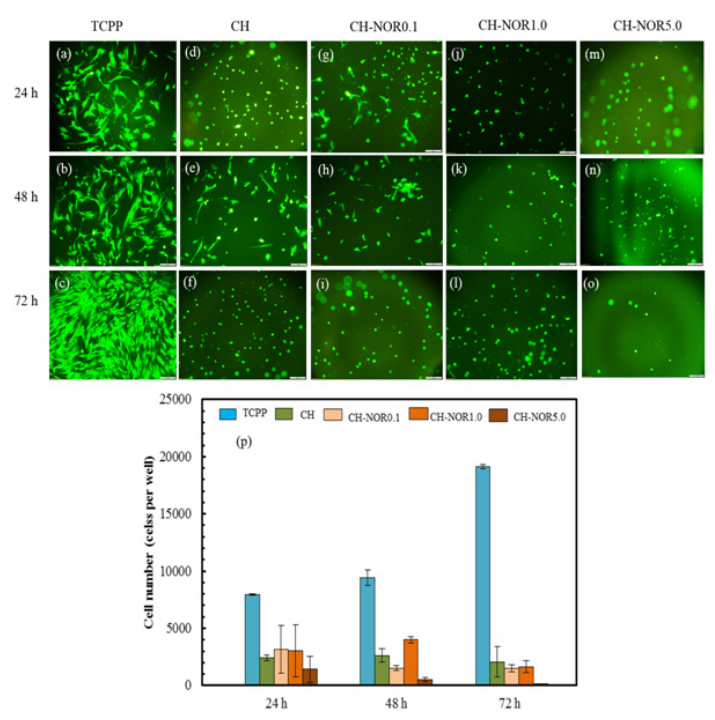

Fig. 3: Fluorescence microscope images of the cell viability on the (a-c) tissue culture polystyrene plate (TCPP), (d-f) CH film, (g-i) CH-NORO.1 film, (j-I) CH-NOR1.0 film, (m-o) CH-NOR5.0 film and (p) cell proliferation of $\mathrm{CH}$ film and $\mathrm{CH}-\mathrm{NORO} .1$, $\mathrm{CH}-\mathrm{NOR} 1.0$ and $\mathrm{CH}-\mathrm{NOR} 5.0$ films cultured in the medium seeded with human skin fibroblast cells (CRL2522) for $24 \mathrm{~h}, 48 \mathrm{~h}$ and $72 \mathrm{~h}$. Scale bars represent $100 \mu \mathrm{m}$.

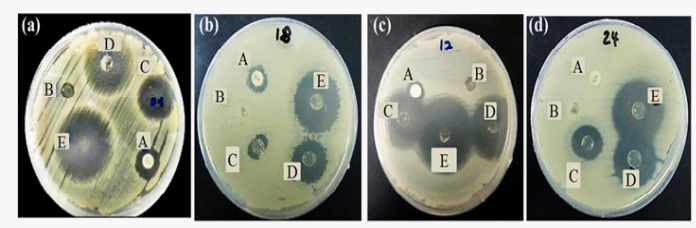

Fig. 4: Qualitative antibacterial property of chitosan film incorporated norfloxacinagaints (a) Staphylococcus aureus, (b) Bacillus cereus, (c) Escherichia coli and (d Klebsiella pneumoniae. The chitosan films were cut into $6 \mathrm{~mm}$ diameter and placed on Muller Hinton agar and labeled as follow; A) Penicillin disc, B) $\mathrm{CH}$ film, C) $\mathrm{CH}$ NOR0.1 film, D) CH-NO1.0 film, and E) CH-NOR5.0 film. recorded 3150 cells/well after incubated for $24 \mathrm{~h}$ and decreased to 1480 cells/well after incubation for $72 \mathrm{~h}$. The same reduction of cell growth was observed for $\mathrm{CH}-\mathrm{NOR} 1.0$ films in which the cell number was recorded at 1630 cells/well (almost similar reading for $\mathrm{CH}-\mathrm{NOR} 0.1$ ) after cultured for $72 \mathrm{~h}$. By adding a higher amount of norfloxacin $(0.23 \mathrm{mg} / \mathrm{mL})$ into $\mathrm{CH}$ film (CH-NOR5.0), the cell growths significantly decreased after being incubated for $72 \mathrm{~h}$. The cell proliferation results are correlated with the limited of fluorescence degree observed on CH-NOR5.0 film.

Limited number of studies have been reported on the influence of norfloxacin to the cell growth. For example, by doing in-vivo test, a group of researcher discovered that chitosan nanocapsules encapsulated with norfloxacin $(5 \mathrm{mg} / \mathrm{mL}$ ) demonstrated an extremely low toxicity effect by examining the histopathological of different organs in rat ${ }^{31}$. In addition to that, ciprofloxacin has a direct effect to fibroblasts, where the exposure to this drug reduced proliferation of three fibroblasts tested $^{32}$. Besides the possible toxicity induces by norfloxacin, a number of studies also reported the influence of physic-chemistry of the material's surface toward biological responses of viable cells such as hydrophilicity and hydrophobicity of materials ${ }^{33}$. Our results show that the swelling behavior of $\mathrm{CH}-\mathrm{NOR} 1.0$ films exhibit optimum water uptake at $524 \pm 65 \%$ as compared to its counterparts. This optimum swelling value could contribute to the moderately wettable substrate and therefore increase the adsorption of serum proteins which eventually enhances cell attachment, spreading and adhesion ${ }^{34}$. This behavior is in agreement with the cell proliferation results of $\mathrm{CH}-\mathrm{NOR} 1.0$ films in which the substrate shown optimum cell number (3990 cell/well) as compared to other $\mathrm{CH}-\mathrm{NOR}$ films.

\section{Antibacterial Study}

The antibacterial activity of the $\mathrm{CH}-\mathrm{NOR}$ films was quantified by a disk method as shown in Fig. 4 and summarized in Table 2. It was observed that $\mathrm{CH}$ film exhibited inhibition against $E$. coli only with a diameter of $7.7 \pm 0.6 \mathrm{~mm}$. In general, chitosan has been reported to show strong inhibition towards E. coli, but differs with several factors such as molecular weight. Previous study on the bactericidal activity of chitosan against $E$. coli has shown that 
Table 2: Inhibition zone area as the indication of antibacterial properties of the chitosan films incorporated norfloxacin against Staphylococcus aureus, Bacillus cereus, Escherichia coli and Klebsiella pneumoniae.

\begin{tabular}{lcccc}
\hline Sample & \multicolumn{3}{c}{ Diameter of inhibition zone (mm) } \\
\hline & $\begin{array}{c}\text { Staphylococcus } \\
\text { aureus }\end{array}$ & Bacilluscereus & $\begin{array}{c}\text { Escherichia } \\
\text { Coli }\end{array}$ & $\begin{array}{c}\text { Klebsiella } \\
\text { pneumoniae }\end{array}$ \\
\hline Penicillin disc & $14.0 \pm 1.7$ & $11.7 \pm 1.53$ & $8.3 \pm 0.6$ & $6.7 \pm 0.6$ \\
$\mathrm{CH}$ & - & - & $7.7 \pm 0.6$ & - \\
$\mathrm{CH}-$ NOR0.1 & $13.6 \pm 0.6$ & $12.3 \pm 1.5$ & $28.7 \pm 1.2$ & $18.0 \pm 2.6$ \\
$\mathrm{CH}-$ NOR1.0 & $31.3 \pm 1.2$ & $22.7 \pm 0.6$ & $34.7 \pm 1.2$ & $24.0 \pm 1.0$ \\
$\mathrm{CH}-$ NOR5.0 & $35.3 \pm 1.2$ & $28.0 \pm 1.0$ & $36.7 \pm 2.3$ & $29.3 \pm 2.1$ \\
\hline
\end{tabular}

chitosan caused lysis and cytoplasmic membrane disruption in $E$. coli observed via ultra-structural analysis using $\mathrm{TEM}^{35}$. The similar study also suggested that the electrostatic interaction between $-\mathrm{NH}_{3}{ }^{+}$groups of chitosan and the negatively charged phospholipids component (carbonyl and phosphoryl groups) of the cell membrane eventually brought about damage to the bacterial cell membrane ${ }^{36}$. Other study has also reported that the release of protonate glucosamine (due to the protonation of amine group) from the chitosan film could contribute to the inhibition of bacterial growth ${ }^{37}$.

With the addition of norfloxacin to the $\mathrm{CH}$ films, the inhibition zones are directly proportional to the amount of norfloxacin added (Table 2). For example, $\mathrm{CH}-\mathrm{NOR} 5.0$ films show the highest inhibition zone to all microbes tested, i.e. $35.3 \pm 1.2 \mathrm{~mm}$, $28.0 \pm 1 \mathrm{~mm}, 36.7 \pm 2.3 \mathrm{~mm}$, and $29.3 \pm 2.1 \mathrm{~mm}$ for Staphylococcus aureus, Bacillus cereus, Escherichia coli and Klebsiella pneumoniae, respectively. The inhibition of bacterial deoxyribonucleic acid (DNA) gyrase and topoisomerase IV gave rise to bactericidal effects of fluoroquinolones antibiotic ${ }^{38}$. A few studies have been reported that norfloxacin is more effective as an antibacterial agent against Gram negative bacteria (Escherichia coli and Klebsiella pneumoniae) than Gram-positive bacteria due to the presence of fluorine atom at $6^{\text {th }}$ position and piperazine moiety in norfloxacin molecular structure $^{39}$. Penicillin on the other hand, is more effective against wide spectrums of Gram-positive bacteria. Almost all strains of Staphylococcus aureus are susceptible to Penicillin ${ }^{40}$ and the same trend was observed in our study. From the data tabulated in Table 2, the inhibition zone of Penicillin on Staphylococcus aureus and Bacillus cereus plates are bigger than those of Escherichia coli and Klebsiella pneumoniae. It can be deduced that, Penicillin is a more powerful antibacterial agent in combating the growth of Gram positive bacteria due to the fact that this antibiotic kills bacteria by inhibiting the proteins which crosslinks peptidoglycans in the cell wall ${ }^{41}$. Besides that, gram positive bacteria like Staphylococcus aureus and Bacillus cereus have no additional layer outside the cell wall, hence causing the bacterium to be susceptible to the attack of Penicillin ${ }^{42}$. Escherichia coli and Klebsiella pneumoniae on the other hand, are Gram negative bacteria which have lipopolysaccharide and protein layer surrounding the peptidoglycan layer of its cell wall, hindering Penicillin from attacking it ${ }^{43}$.

\section{CONCLUSIONS}

The chitosan film with norfloxacin $(\mathrm{CH}$ NOR) has been successfully prepared. Addition of norfloxacin into $\mathrm{CH}$ film increased the strain-atbreak to $80 \pm 1 \%$ than $\mathrm{CH}$ film at $69 \pm 6 \%$ at a cost of decreased the tensile strength. Swelling behavior of the $\mathrm{CH}-\mathrm{NOR}$ films are increased and reached optimum at $524 \pm 65 \%$, while water vapor transmission rates of all films are within the range of commercial dressings (1682-1916 $\left.\mathrm{g} \mathrm{m}^{-2} \mathrm{~d}^{-1}\right)$. The in-vitro cell study shows norfloxacin in $\mathrm{CH}$ film perturbed the cell growth at higher concentration $(0.23 \mathrm{mg} / \mathrm{mL})$ and longer incubation (72 h). However, inclusion of norfloxacin at higher amount significantly improved the antibacterial activity of $\mathrm{CH}$ film against Gram positive (S. aureas, B. cereus) and Gram negative (E. coli, K. pneumoniae). 


\section{ACKNOWLEDGMENTS}

The authors wish to thank Ministry of Higher Education for financial assistance under Research
Acculturation Grant Scheme (RAGS, Grant no. 57080) and the Institute of Biotechnology Marine, Universiti Malaysia Terengganu for providing the facilities in undertaking this work.

\section{REFERENCES}

1. Zhang, D.; Zhou, W.; Wei, B.; Wang, X.; Tang, R.; Nie, J.; Wang, J. Carbohydrate polymers 2015,125, 189-199.

2. Galli, C.; Parisi, L.; Elviri, L.; Bianchera, A.; Smerieri, A.; Lagonegro, P.; Lumetti, S.; Manfredi, E.; Bettini, R.; Macaluso, G. Biomedical Materials 2016,11, 015004.

3. Xu, J.; Strandman, S.; Zhu, J. X.; Barralet, J.; Cerruti, M. Biomaterials 2015,37, 395-404.

4. Behl, G.; lqbal, J.; O’Reilly, N. J.; McLoughlin, P.; Fitzhenry, L. Pharmaceutical research 2016, 1-11.

5. Karthik, R.; Manigandan, V.; Saravanan, R.; Rajesh, R. P.; Chandrika, B. Int. J. Biol. Macromol. 2016,84, 319-328.

6. Azuma, K.; Osaki, T.; Minami, S.; Okamoto, Y. Journal of functional biomaterials 2015,6, 33-49.

7. Jayakumar, R.; Prabaharan, M.; Sudheesh Kumar, P.T.; Nair, S. V.; Tamura, H. Biotechnol. Adv. 2011,29, 322-337.

8. Sezer, A. D.; Hatipoglu, F.; Cevher, E.; Oðurtan, Z.; Bas, A. L.; Akbuða, J. AAPS PharmSciTech 2007,8, E94-E101.

9. Noel, S. P.; Courtney, H.; Bumgardner, J. D.; Haggard, W. O. Clinical Orthopaedics and Related Research 2008,466, 1377-1382.

10. Wang, Q.; Dong, Z.; Du, Y.; Kennedy, J. F. Carbohydrate polymers 2007,69, 336-343.

11. Wang, L.-C.; Chen, X.-G.; Zhong, D.-Y.; Xu, Q.-C. Journal of Materials Science: Materials in Medicine 2007, 18, 1125-1133.

12. Garrison, M. W. Diagnostic Microbiology and Infectious Disease 2006,54, 51-56.

13. Santoro, M. I. R. M.; Kassab, N. M.; Singh, A. K.; Kedor-Hackmam, E. R. M. Journal of Pharmaceutical and Biomedical Analysis 2006,40, 179-184.

14. Hadimeri, H.; Almroth, G.; Cederbrant, K.; Eneström, S.; Hultman, P.; Lindell, Å. Scandinavian journal of urology and nephrology 1997,31, 481-485.

15. Lindgren, P. K.; Marcusson, L. L.; Sandvang, D.; Frimodt-Møller, N.; Hughes, D. Antimicrobial Agents and Chemotherapy 2005,49, 23432351.

16. Campillo, B.; Dupeyron, C.; Richardet, J.-P.; Mangeney, N.; Leluan, G. Clinical infectious diseases 1998,26, 1066-1070.

17. Denkbaoo, E. B.; Öztürk, E.; Özdemir, N.; Keçeci, K.; Agalar, C. J. Biomater. Appl. 2004, 18, 291-303.

18. XUE, C.-g.; TONG, C.-y.; XIAO, S.-y.; WANG, B.;YU, D.-m.; TANG, D.-y.; LIU, X.-m. Journal of Central South University (Science and Technology) 2008,3, 013.

19. Dua, K.; Ramana, M. V.; Sara, U. V. S.; Agrawal, D. K.; Pabreja, K.; Chakravarthi, S. Eplasty 2010,10, e44.

20. Mishra, R.; Majeed, A.; Banthia, A. International Journal of Plastics Technology 2011, 15, 8295.

21. Pierog, M.; Gierszewska-Dru¿yñska, M.; Ostrowska-Czubenko, J. Progress on Chemistry and Application of Chitin and its Derivatives. Polish Chitin Society, £ód Ÿ 2009,75, 82.

22. Sarasam, A.; Madihally, S. V. Biomaterials 2005,26, 5500-5508.

23. Nagahama, H.; Maeda, H.; Kashiki, T.; Jayakumar, R.; Furuike, T.; Tamura, H. Carbohydrate Polymers 2009,76, 255-260.

24. Qu, X.; Wirsén, A.; Albertsson, A. C. Polymer 2000,41, 4589-4598.

25. Varshosaz, J.; Koopaie, N. Iranian Polymer Journal 2002,11, 123-131.

26. Fu, S.-Y.; Feng, X.-Q.; Lauke, B.; Mai, Y.-W. Composites Part B: Engineering 2008,39, 933-961.

27. Wu, P.; Fisher, A.; Foo, P.; Queen, D.; Gaylor, J. Biomaterials 1995, 16, 171-175.

28. Srinivasa, P.; Ramesh, M.; Kumar, K.; 
Tharanathan, R. Journal of Food Engineering 2004,63, 79-85.

29. Ding, Z.; Chen, J.; Gao, S.; Chang, J.; Zhang, J.; Kang, E. T. Biomaterials 2004,25, 10591067.

30. Howling, G. I.; Dettmar, P. W.; Goddard, P. A.; Hampson, F. C.; Dornish, M.; Wood, E. J. Biomaterials 2001,22, 2959-2966;

31. Rapã, D.; Popa, M.; Chailan, J.-F.; Zamfir, C.; Peptu, C. Journal of Nanoparticle Research 2014, 16, 1-10.

32. Williams, R. J.; Attia, E.; Wickiewicz, T. L.; Hannafin, J. A. The American journal of sports medicine 2000,28, 364-369.

33. Ruardy, T. G.; Moorlag, H. E.; Schakenraad, J. M.; Van Der Mei, H. C.; Busscher, H. J. Journal of Colloid and Interface Science 1997,188, 209-217.

34. Van Wachem, P.; Beugeling, T.; Feijen, J.; Bantjes, A.; Detmers, J.; Van Aken, W. Biomaterials 1985,6, 403-408.

35. Li, X.-f.; Feng, X.-q.; Yang, S.; Fu, G.-q.;
Wang, T.-p.; Su, Z.-x. Carbohydrate Polymers 2010,79, 493-499.

36. Liu, H.; Du, Y.; Wang, X.; Sun, L. International journal of food microbiology 2004,95, 147155.

37. Fernandez-Saiz, P.; Lagaron, J.; Ocio, M. Food Hydrocolloids 2009,23, 913-921.

38. Gürbay, A.; Garrel, C.; Osman, M.; Richard, M.; Favier, A.; Hincal, F. Human \& experimental toxicology 2002,21, 635-641.

39. Sharma, P. C.; Saneja, A.; Jain, S. Int J Chem Sci 2008,6, 1702-1713.

40. Rice, L. B. American journal of infection control 2006,34, S11-S19.

41. Fair, R. J.; Tor, Y. Perspectives in medicinal chemistry 2014,6, 25.

42. Feng, Q.; Wu, J.; Chen, G.; Cui, F.; Kim, T.; Kim, J. Journal of biomedical materials research 2000,52, 662-668.

43. Beveridge, T. J. J. Bacteriol. 1999, 181, 47254733. 